\title{
Decreased web investment in sub-tropical Nephila clavata (Tetragnathidae)
}

\author{
Claire K. Cartan ${ }^{1)} \&$ Tadashi Miyashita ${ }^{1)}$ \\ カルタン和美 ${ }^{1)} ・$ 宮下 直 ${ }^{1)}$ : 亜熱帯のジョロウグモにおける \\ 網投資量の減少
}

\begin{abstract}
Webs of Nephila clavata living in Okinawa, a sub-tropical region of Japan, were found to be significantly smaller and to have less number of radii and spirals than those seen in temperate Tokyo. According to recent papers, a web is thought to get smaller when prey is abundant (Sherman 1994), or before molting and egg-laying (Higgins 1990), but none of these explain web reduction in Okinawa. We propose an alternative explanation: the necessity of the spider to adjust its life cycle to a sub-tropical climate.
\end{abstract}

\section{Introduction}

Many papers have been published which compare the function or the adaptiveness of web design among orb-weaving spiders (e.g. Olive 1980). However, little attention have been paid to intraspecific variation. Only a few papers treated this subject: Sherman (1994) reported that a hungry individual of Larinioides cornutus built a larger, wider-meshed web, and that the total length of silk utilizied in the web and mesh density of spirals were both positively correlated with the previous night temperature. Higgins (1990) found that webs decreased in diameter but not in mesh density prior to molting and reproduction. A colonial South American spider, Parawixia bistriata, was found to build much wider-meshed and bigger webs only on rainy days in September when termites swarmed, although their usual nocturnal web was smaller and finer-meshed (Sandoval 1994).

However, these changes in webs seem to occur at the individual level as a consequence of environmental changes or of the physiology of the spider, not as an expression of the genotype. Only in Higgins (1992a, 1992b) can we find a description of differences in web characteristics between two geographically isolated populations. Even in this case, she found more differences within a site in two different seasons than between two isolated sites.

However, geographic variations in life history traits being a widely and commonly occurring phenomenon in organisms including arthropods (e.g., Denno \& Dingle 1981), it may well be seen in spider webs also. Thus, we aim in this paper to investigate differences in orb webs of Nephila clavata living in temperate Honshu and those living far south away, in sub-tropical Okinawa islands.

1) Laboratory of Wildlife Biology, School of Agriculture \& Life Sciences, University of Tokyo, Bunkyo-ku, Tokyo, 113-8657 Japan

東京大学大学院農学生命科学研究科野生動物学研究室 ₹ 113-8657 東京都文京区弥生 1-1-1

Accepted May 20, 1998 

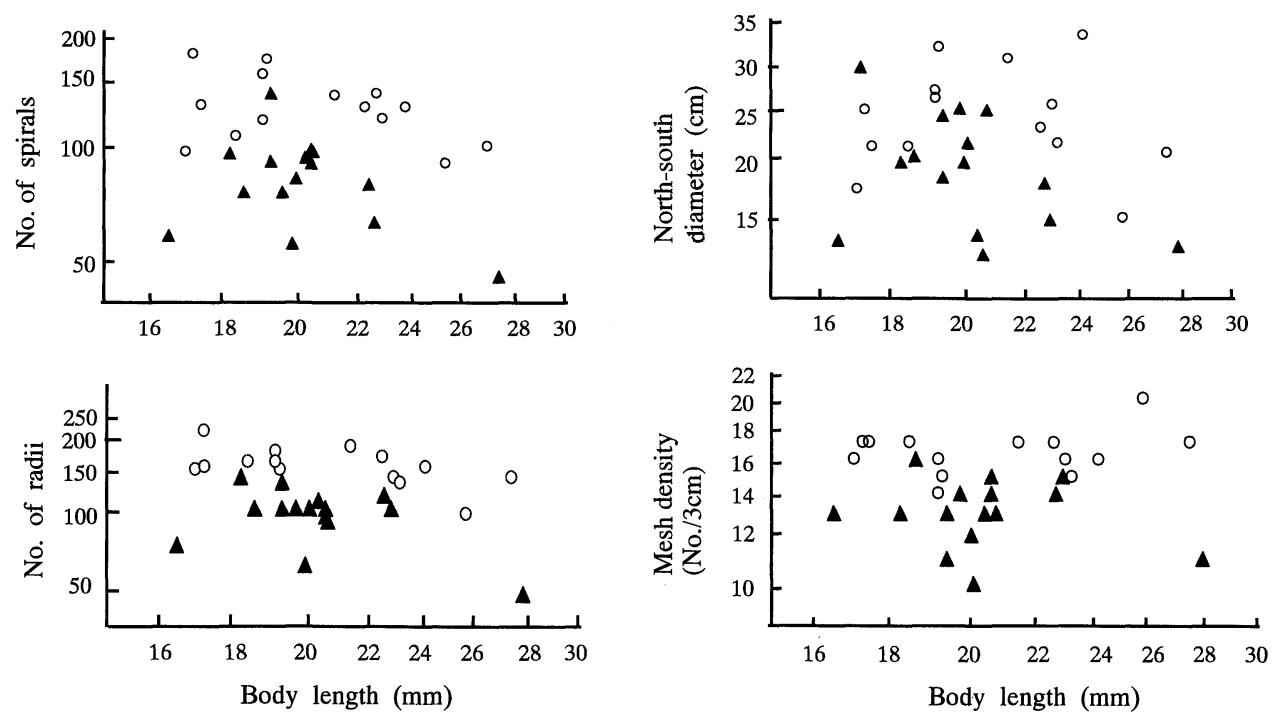

Fig. 1. Structure of webs of Nephila clavata living in Tokyo (open circles) and in Okinawa (solid triangles).

\section{Methods}

We measured several characteristics of the webs of female $N$. clavata larger than 16 $\mathrm{mm}$ in body length in two geographically isolated sites: Mizumoto Park and Koishikawa Botanical Park in temperate Tokyo, road cuts in woods in Nago city and Nakijin city on sub-tropical Okinawa main island.

We defined in this paper the top of web as "north" and the bottom of web as "south", and examined the following characteristics: north-south and east-west diameter of webs, the number of radii, the number of spiral threads between the hub and south, and the number of spiral threads per $3 \mathrm{~cm}$ in the middle of an imaginary line joining the hub and south-east (mesh density).

As there seemed to be no relationship between body length and web parameters due to the small variation in body length (Fig. 1), we used $t$-test instead of ANCOVA.

\section{Results}

Figure 1 shows web features of $N$. clavata in Tokoyo and in Okinawa. There were significant differences in north-south web diameter $(t=-5.055, p=0.002)$, in the number of spirals $(t=-4.401, p=0.007)$, in the number of radii $(t=-4.824, p=$ $0.0003)$, and in mesh density $(t=-6.433, p<0.0001)$. This implies that spiders in Okinawa invest less silk material in their webs than those of Tokyo.

\section{Discussion}

We will consider the reasons for the differences in web investment of $N$. clavata from the following points of view: developmental status, temperature of the environment, prey availability, and life cycle. 
Webs of $N$. clavata were significantly smaller in Okinawa than in Tokyo. According to the papers discussing about webs of relatively small size, small or young spiders are builders of small webs (Risch 1977), but older spiders reduce the size of their webs also prior to molting and egg-laying (Higgins 1990). This cannot be the case however in Okinawa spiders, which were of similar size to those of Honshu, and were one to four months ahead of egg-laying. It is also hardly possible that all spiders were ready to molt at the same time.

Sherman (1994) found that silk length was positively correlated with night temperature, though its reason was unknown. As the temperature in Okinawa is higher throughout the year than in Tokyo, to match with this finding, webs should be larger and mesh density higher. Since this is not the case, we must consider another factor is working.

Sherman (1994) reported also that hungry spiders build larger webs and that a relationship exists between web size and amount of prey captured. Thus, we might expect higher prey capture rate in Okinawa. In order to estimate the amount of prey, Miyashita (1992) observed adults N. clavata in Tokyo and found 10 to $30 \%$ of them eating prey, while our observations on $N$. clavata in Okinawa gave the low percentage of $7.3 \%(3 / 41)$ prey capture (personal observation). Since these results contradict with the above predictions, differences in prey availability cannot explain the lower web investement in the Okinawa population.

Lastly we will consider the possibility that the spider adjusts its life cycle to different environments. $\quad N$. clavata is the farthest north living spider in its genus, and Okinawa is one of its south limit. Having evolved in colder regions, it may be programed to have only one generation per year (Shimojana 1971). Okinawa spiders hatch from February to April, and grow up to lay eggs and die between December and March (Kurihara 1977). A total of 8 to 11 months is an amazing long life compared to the life length of those of Honshu, which appear around June to disappear around November (Miyashita 1986). Not being able to have two generations, and the climate being warm during most of the year, Okinawa spiders may have developed an unusually long life compared to those of colder regions. Their long, slow growth may have come to be possible as a result of consuming fewer prey caught in small webs, while $N$. clavata in colder regions have to hasten to grow up, eating as much prey as possible, before winter comes.

Therefore decreased web investment in the Okinawa population appears to be an adaptation for maintaining one generation per year under a sub-tropical climate.

\footnotetext{
摘要

亜熱帯地域である沖縄に生息するジョロウグモの網は, 温帯の東京に生息するジョロ ウグモの網よりも有意に面積が小さく, 縦系および横系の本数が少なかった. 最近の研 究によると, クモは満腹時, 産卵前, 脱皮前に網への投資量を減少させることが知られ ているが, 沖縄のジョロウグモの網の特性はこれらのいずれによっても説明できない. 我々はこの現象について, 业熱帯の気候に対する生活環の調節の観点から考察を試みた。
} 


\section{References}

Denno, R. F. \& Dingle, H. 1981. Insect Life History Patterns: Habitat and Geographic Variation. Spring-Verlag, New York.

Higgins, L. E., 1990. Variation in foraging investment during the intermolt interval and before egg-laying in the spider Nephila clavipes. J. Insect Behav., 3: 773-783.

Higgins, L. E., 1992a. A trap-building predator exhibits different tactics for different aspects of foraging behaviour. Anim. Behav., 44: 485-499.

Higgins, L. E., 1992b. Developmental changes in barrier webs structure under different levels of predation risk in Nephila clavipes. J. Insect Behav., 5: 635-655.

Kurihara, K., 1977. Geographic variation in Nephila clavata. Atypus, 70: 48-49. (In Japanese:)

Miyashita, T., 1986. Growth, egg production and population density of the spider Nephila clavata in relation to food conditions in the field. Res. Popul. Ecol., 28: 135-149.

Miyashita, T., 1992. Variability in food consumption rate of natural populations in the spider Nephila clavata. Res. Popul. Ecol., 34: 15-28.

Olive, C. W., 1980. Foraging speciation in orb-weaving spiders. Ecology, 61: 1133-44.

Risch, P., 1977. Quantitative analysis of orb web pattern in four species of spiders, Behaviour Genetics. 7: 199-238.

Sandoval, C. P., 1994. Plasticity in web design in the spider Parawixia bistriata: a response to variable prey type. Funct. Ecol., 8: 701-707.

Sherman, P. M, 1994. The orb-web: an energetic and behavioural estimator of a spider's dynamic foraging and reproductive strategies. Anim. Behav., 48: 19-34.

Shimojana, M., 1971. Studies on genus Nephila in Okinawa Island (1) Studies on the life cycle of Nephila clavata. Biol. Mag. Okinawa, 7: 1-18. (In Japanese.) 